\title{
Cytosolic alkalinization is a common and early messenger preceding the production of ROS and NO during stomatal closure by variable signals, including abscisic acid, methyl jasmonate and chitosan
}

Vijay K. Gonugunta, Nupur Srivastava and Agepati S. Raghavendra*

Department of Plant Sciences; School of Life Sciences; University of Hyderabad; Hyderabad, India

Key words: abscisic acid, methyl jasmonate, chitosan, cytosolic $\mathrm{pH}$, reactive oxygen species, $\mathrm{H}_{2} \mathrm{O}_{2}$, nitric oxide, cytosolic calcium

Stomata are unique that they sense and respond to several internal and external stimuli, by modulating signaling components in guard cells. The levels of reactive oxygen species (ROS), nitric oxide (NO) and cytosolic calcium $\left(\mathrm{Ca}^{2+}\right)$ increase significantly during stomatal closure by not only plant hormones [such as abscisic acid (ABA) or methyl jasmonate (MJ)] but also elicitors (such as chitosan). We observed that cytosolic alkalinization preceded the production of ROS as well as NO during ABA induced stomatal closure. We therefore propose that besides ROS and $\mathrm{NO}$, the cytosolic $\mathrm{pH}$ is an important secondary messenger during stomatal closure by $\mathrm{ABA}$ or $\mathrm{MJ}$. We also noticed that there is either a cross talk or feedback regulation by cytosolic $\mathrm{Ca}^{2+}$ and $\mathrm{ROS}$ (mostly $\mathrm{H}_{2} \mathrm{O}_{2}$ ). Further experiments on the interactions between cytosolic $\mathrm{pH}, \mathrm{ROS}, \mathrm{NO}$ and $\mathrm{Ca}^{2+}$ would yield interesting results.

\section{Introduction}

Dynamic regulation of stomatal aperture in leaves is essential for optimizing the balance between transpirational water loss and $\mathrm{CO}_{2}$ entry into intracellular spaces required for photosynthesis. Such balance is achieved by the ability of two guard cells, which flank stomata, to sense and integrate multiple internal and external stimuli. ${ }^{1,2}$ Stomatal opening is promoted by light, low $\mathrm{CO}_{2}$, fusicoccin (FC) and hormones including indoleacetic acid (IAA) and cytokinins. In contrast, stomatal closure is induced by high $\mathrm{CO}_{2}$, darkness, low humidity and hormones such as abscisic acid (ABA) or methyl jasmonate (MJ). Among the many factors that induce

*Correspondence to: Agepati S. Raghavendra; Department of Plant Sciences; School of Life Sciences; University of Hyderabad; Hyderabad 500046 India; Fax: +91.40.23010120; Email: asrs@@uohyd.ernet.in

Submitted: 04/19/09; Accepted: 04/22/09

Previously published online as a Plant Signaling \& Behavior E-publication: http://www.landesbioscience.com/journals/psb/article/8847

Addendum to: Gonugunta VK, Srivastava N, Puli MR, Raghavendra AS. Nitric oxide production occurs after cytosolic alkalinization during stomatal closure induced by abscisic acid. Plant Cell Environ 2008; 31:1717-24; PMID: 18721267; DOI: 10.1111/j.1365-3040.2008.01872.x. stomatal closure, the effects of ABA received maximum. ${ }^{1-3}$ Several of the secondary messengers are common during the transduction of these signals, notably cytosolic free $\mathrm{Ca}^{2+}$, reactive oxygen species (ROS), nitric oxide (NO) and G-proteins, which have been extensively studied. Besides the above, ABA modulates several other signaling components in guard cells, such as cytosolic $\mathrm{pH}$, protein kinases, protein phosphatases, phospholipases and phosphatidylinositol kinases during stomatal closure. ${ }^{4-9}$

ROS and NO act as secondary messengers in not only guard cells but also other plant tissues, while mediating developmental and physiological processes such as programmed cell death, root development, hypersensitive responses and adaptation to stress conditions. ${ }^{9-12}$ In guard cells of several species (Arabidopsis, Vicia, tomato, Commelina and pea) production of ROS and NO occurs in response to $\mathrm{ABA}, \mathrm{MJ}$, bicarbonate or even chitosan/oligogalacturonic acid. $., 7,12-16$ The involvement of ROS and NO during stomatal closure was further demonstrated by additional evidences: modulation of ROS or NO levels within cells by either scavenging these molecules or inhibition of source enzymes and finally real time monitoring of ROS/NO by using fluorescent dyes.

Calcium $\left(\mathrm{Ca}^{2+}\right)$ is another ubiquitous intracellular second messenger, involved in many signal transduction pathways in both plants and animals. The cytosolic $\mathrm{Ca}^{2+}$ concentration is modulated in response to many physiological stimuli and is delicately balanced by ' $\mathrm{Ca}^{2+}$ stores', like vacuoles, endoplasmic reticulum, mitochondria, nucleus, chloroplast and cell wall. ${ }^{17}$ For example, when proteinaceous elicitors were used as signals, the $\mathrm{Ca}^{2+}$ patterns were clearly different in the cytosol and the nucleus. ${ }^{18}$ Upon treatment with cryptogein, a polypeptidic elicitor, a substantial but transient increase in cytosolic $\mathrm{Ca}^{2+}$ took place, peaking 5 min posttreatment, and was followed by a sustained cytosolic $\mathrm{Ca}^{2+}$ elevation which lasted for at least 2 h. ${ }^{19}$

The $\mathrm{pH}$ inside a cell tends to be quite stable and may vary only by a small fraction of a unit, but even with such small change, $\mathrm{pH}$ can mediate and exert strong physiological and biochemical responses. For example, application of ABA to plant cells raises the $\mathrm{pH}$ of cytosol by approximately $0.2-0.4$ units within minutes. Cytoplasmic alkalinization is a major step in the ABA-triggered 


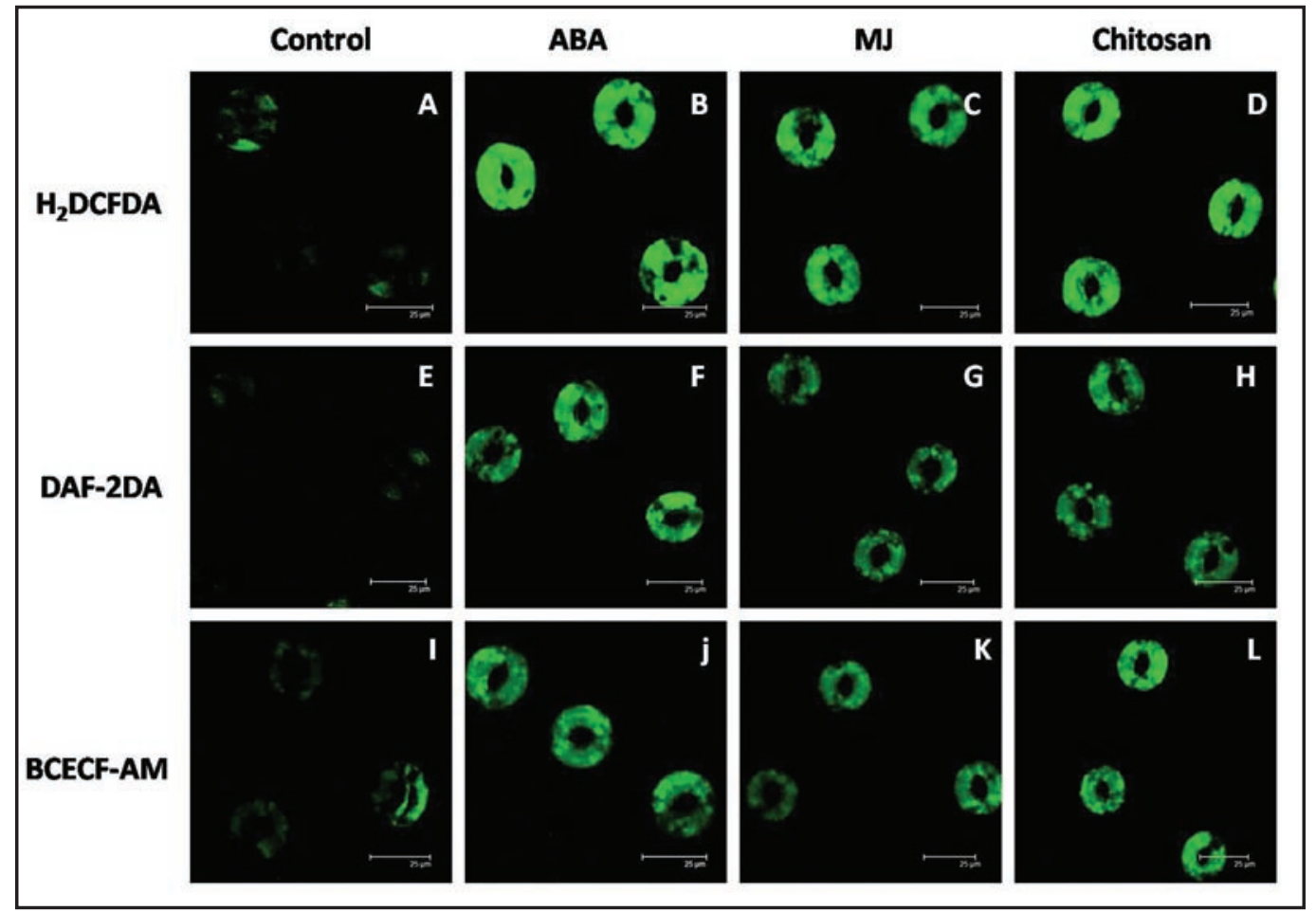

Figure 1. Confocal images showing elevation of ROS (indicated by the fluorescence of $\mathrm{H}_{2}$ DCFDA), NO (DAF-2DA) or cytosolic pH (BCECF-AM) by 10 $\mu \mathrm{M} \mathrm{ABA}$ or $20 \mu \mathrm{M} \mathrm{N}$ or $5 \mu \mathrm{g} \mathrm{ml}^{-1}$ chitosan in guard cells of Pisum sativum. The (B-D, F-H and J-L) are the epidermal strips treated with $10 \mu$ lethanol containing $10 \mu \mathrm{M} \mathrm{ABA}, 20 \mu \mathrm{M} \mathrm{M}$ and $5 \mu \mathrm{g} \mathrm{ml} \mathrm{H}^{-1}$ chitosan, respectively. (A, E and I) are the epidermal strips treated with $10 \mu \mathrm{l}$ ethanol, as controls. $(A-D)$ represents the patterns of ROS levels, and the $(\mathrm{E}-\mathrm{H}$ and $\mathrm{I}-\mathrm{L})$ represent the images of $\mathrm{NO}$ and $\mathrm{pH}$, respectively. Confocal fluorescence images were taken at $18 \mathrm{~min}$ after addition of individual effectors. Experimental details are further described. ${ }^{14,26}$ Bar $=25 \mu \mathrm{m}$.

signal cascade in guard cells leading to $\mathrm{H}^{+}$efflux and stomatal closure. ${ }^{4,20}$ Such intracellular $\mathrm{pH}$ alterations play an important role in a variety of processes including, plant defense, coleoptile or root hair growth, nodulation, elicitation ${ }^{21-25}$ and response to hormones such as ABA and MJ.6,26

We have been studying the role of not only ROS or NO, but also cytosolic $\mathrm{pH}$ as signaling components. We characterized the temporal sequence of changes in the level of $\mathrm{pH}, \mathrm{ROS}$ and $\mathrm{NO}$ in guard cells on exposure to ABA or MJ. Our experiments were based on three approaches: (i) Bioassay of stomatal closure by $\mathrm{ABA}$ or $\mathrm{MJ}$ in presence of pharmacological compounds capable of modulating the different secondary messengers; (ii) Modulation of the secondary messengers by promoters, scavengers; and finally (iii) Direct monitoring of ROS, $\mathrm{NO}$ or cytosolic $\mathrm{pH}$ by fluorescent dyes. In some of the experiments mutants deficient in $\mathrm{NADPH}$ oxidase or insensitive to ABA or MJ were also used.

While examining the pattern and mechanisms of stomatal closure by plant hormones (ABA, MJ), a fungal elicitor (chitosan) and bicarbonate (simulating high $\mathrm{CO}_{2}$ ), 6,7,13,14,27 we found that ROS or $\mathrm{NO}$ are important signaling components during stomatal closure by these different factors. Further cytoplasmic alkalinization is an early and common component during stomatal closure induced by not only ABA or MJ but also chitosan (Fig. 1).

\section{Change in pH of Guard Cells on Exposure to ABA or MJ is an Early Event}

Changes in $\mathrm{pH}$ of guard cells have been observed on exposure to hormones such as ABA/MJ or fungal toxin such as $\mathrm{FC}$ or even an elicitor such as chitosan. In epidermal strips of Pisum sativum or an orchid, Paphiopedilum tonsum, application of ABA or weak alkalinizing agents, such as benzylamine or methylamine, enhanced the cytosolic $\mathrm{pH}$ and promoted stomatal closure. ${ }^{8,26} \mathrm{FC}$, IAA or a weak acid butyrate, decreased the cytosolic $\mathrm{pH}$ and promoted stomatal opening. ${ }^{4,26}$ Thus, stomatal opening was accompanied by decrease in cytosolic $\mathrm{pH}$, whereas stomatal closure was preceded by cytosolic alkalinization in the guard cells.

Irving group reported that acidification of guard cell cytosol by kinetin, IAA or FC preceded stomatal opening, whereas alkalinization of guard cell cytosol occurred prior to stomatal closure in response to ABA. These results strongly suggested that cytosolic $\mathrm{pH}$ was a key factor in the regulation of guard cell movement. However there is an ambiguity, whether enhanced cytosolic $\mathrm{pH}$ or cytosolic alkalinization leads to production of $\mathrm{H}_{2} \mathrm{O}_{2}$. Zhang group suggested that application of $\mathrm{H}_{2} \mathrm{O}_{2}$ to the guard cells lead to increase in cytosolic $\mathrm{pH}$, which further decreased the stomatal aperture. Our results confirmed that stomatal closure was preceded by the modulation of $\mathrm{pH}$ in guard cells. ${ }^{6,26}$ Direct real time monitoring of ROS, $\mathrm{NO}$ or $\mathrm{pH}$, by fluorescence probes revealed that the cytosolic alkalinization occurs much before the rise in ROS or 


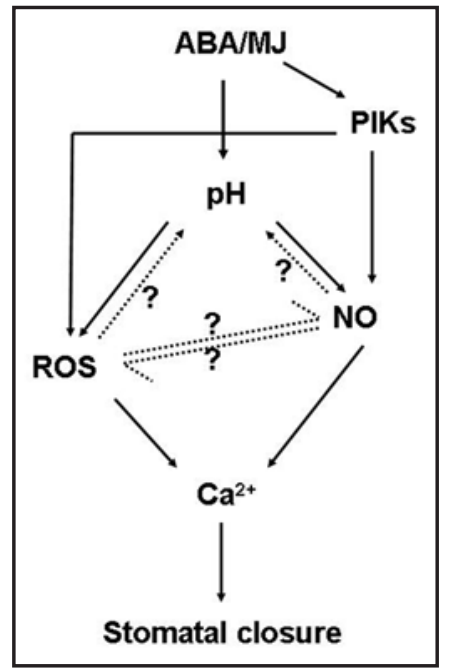

Figure 2. Schematic representation of the signaling cascade, leading to the stomatal closure by $\mathrm{ABA}$ or $\mathrm{M}$. The rise in cytosolic $\mathrm{pH}$ leads to the elevation of the ROS as well as in NO in guard cells. Both ROS and NO lead to rise in cytosolic $\mathrm{Ca}^{2+}$ and subsequent stomatal closure. A feedback regulation by $\mathrm{ROS}$ and $\mathrm{NO}$ on $\mathrm{pH}$ appears to operate. These interactions between $\mathrm{pH}, \mathrm{ROS}$ and $\mathrm{NO}$ need further detailed examination. The sequence of changes for which the evidences are either ambiguous or lacking, are indicated by dotted arrows, while the well-established events are represented by solid arrows.

$\mathrm{NO}$ during stomatal closure by $\mathrm{ABA}$ or $\mathrm{MJ}$. The $\mathrm{pH}$ rise appears to be necessary and occurring downstream of the ROS production during ABA-induced stomatal closure. The modulation of cytosolic $\mathrm{pH}$ changed the patterns of $\mathrm{NO}$ production and stomatal closure but not the ROS production. Similarly, the NO modulators such as CPTIO (NO scavenger) and L-NAME (inhibitor of NO-production) did not affect the cytosolic $\mathrm{pH}$ changes, ${ }^{26}$ we are of the opinion that cytosolic $\mathrm{pH}$ change is necessary and occurs upstream of the NO elevation in guard cells.

Studies on temporal kinetics of changes in $\mathrm{pH}, \mathrm{ROS}$ and $\mathrm{NO}$ can help in identifying the exact sequence of events. In Paphiopedilum tonsum, the modulation of $\mathrm{pH}$ by IAA, FC or kinetin ( $\mathrm{pH}$ decrease) or $\mathrm{ABA}$ ( $\mathrm{pH}$ increase) required 5 to $10 \mathrm{~min} .{ }^{4}$ However, we noticed that it took 18 minutes to attain maximum cytosolic $\mathrm{pH}$ by application of $10 \mu \mathrm{M} \mathrm{ABA}$. As these reports are quite limited in number, further experiments would be necessary to examine the kinetics of $\mathrm{pH}$ changes in guard cells during stomatal closure as well as stomatal opening.

\section{Consequences of pH Modulation on Signaling Components and Stomatal Closure}

The weak acids cross the membrane in the uncharged form and dissociate in the cytosol, thereby decreasing the $\mathrm{pH} .{ }^{25}$ Weak acids such as butyrate and propionic acid can acidify plant cells and cause significant changes in $\mathrm{pH} .{ }^{28}$ Such acidification can hyperpolarize the membrane. However, lowering cytosolic $\mathrm{pH}$ was associated with an increase in cytosolic $\mathrm{Ca}^{2+}$ and inactivation of inward-rectifying $\mathrm{K}^{+}$channels. ${ }^{20,25}$ We showed that acidification of guard cells by butyrate restricted the stomatal closure by $\mathrm{ABA}$ and alkalinization by methylamine enhanced the stomatal closure. ${ }^{26}$
Depolarization could be achieved by $\mathrm{Ca}^{2+}$ influx facilitated by activated $\mathrm{Ca}^{2+}$ channels ${ }^{2}$ and/or by cytosolic alkalinization, which would reduce the activity of the proton pump. Anionic channels conducting chloride and malate are activated by depolarization, elevated cytosolic $\mathrm{Ca}^{2+}$ and this would lead to loss of anions and further depolarization. ${ }^{2,29}$ Thus, increases in both cytosolic $\mathrm{pH}$ and $\mathrm{Ca}^{2+}$ would have a synergistic effect on the depolarization of plasma membrane in guard cells.

Procaine, a weak base, has also been used to alkalinize plant cells. $^{25,30}$ Procaine increases rapidly cytosolic $\mathrm{pH}$ by 0.1 to 0.4 units within $5 \mathrm{~min}$. However, no increase in cytosolic $\mathrm{Ca}^{2+}$ was observed in guard or epidermal cells in response to procaine. ${ }^{4} \mathrm{On}$ the contrary, a slight decrease in cytosolic $\mathrm{Ca}^{2+}$ of Sinapis alba root hairs was seen on exposure to procaine. Some of these anomalies have to be reexamined, so as to establish, if the $\mathrm{pH}$ rise in guard cells is a causal factor or an associated event during stomatal opening/closure.

\section{Intriguing Effects of $\mathrm{Ca}^{2+}$ : Possible Dual Role and Increase during Even Opening}

Rise in cytosolic free $\mathrm{Ca}^{2+}$ is a common event during stomatal closure caused by $\mathrm{ABA}$ or $\mathrm{H}_{2} \mathrm{O}_{2}$ and even fungal elicitors such as chitosan/oligogalacturonic acid. Such action of $\mathrm{Ca}^{2+}$ upstream of changes in ROS or NO levels was observed by several workers. ${ }^{15,26}$ The rise in cytosolic $\mathrm{pH}$ could be a trigger for the rise in cytoplasmic $\mathrm{Ca}^{2+}$, but this needs experimental validation. The increase in cytosolic $\mathrm{Ca}^{2+}$ can be caused by the simulation of $\mathrm{Ca}^{2+}$ influx across the plasma membrane and/or release from internal sources, which include endoplasmic reticulum, vacuole and mitochondria. Cytosolic $\mathrm{Ca}^{2+}$ signatures have been postulated to act as the second messengers in both stomatal opening and closure in response to biotic and abiotic stress conditions. ${ }^{17}$

However it is yet to be ascertained if change in $\mathrm{pH}$ can modulate internal $\mathrm{Ca}^{2+}$ or $\mathrm{Ca}^{2+}$ in turn affects the cytosolic $\mathrm{pH}$. Also, the changes in cytosolic $\mathrm{Ca}^{2+}$ of guard cell protoplasts after ABA treatment were quite variable. ${ }^{3,17}$ Since stomatal closure occurred, despite the ambiguous, observations on $\mathrm{Ca}^{2+}$ changes, it was suggested that a $\mathrm{Ca}^{2+}$-independent mechanism might operate during the $\mathrm{ABA}$-induced closure of stomata. ${ }^{3}$ Further, factors which can induce stomatal opening, such as IAA, FC and kinetin also enhanced cytosolic $\mathrm{Ca}^{2+} \cdot{ }^{2}$ Experiments need to be designed to establish clearly, if $\mathrm{Ca}^{2+}$ can play a dual role: upstream and downstream of ROS/NO production.

\section{Future Perspective}

Besides the direct influence of $\mathrm{pH}$ on ROS or NO levels, it is possible that these components exert interactive effects. Since the $\mathrm{NO}$-molecule is quite active at an alkaline $\mathrm{pH}$ of $7.4,{ }^{31} \mathrm{NO}$ can be expected to become very effective as the $\mathrm{pH}$ rises. The combination of ROS and NO result in peroxynitrite radicals, which can affect the cell. ${ }^{32}$ Thus, the effects of ROS or NO may be enhanced at alkaline $\mathrm{pH}$, besides the interactions of ROS or $\mathrm{NO}$ between them. It is not clear that, if the change in cytosolic $\mathrm{pH}$ is necessary for $\mathrm{NO}$ production or is an associated event during stomatal closure by different stimuli. A schematic representation of possible events 
occurring during $\mathrm{ABA}$ induced stomatal closure as can be agreed at present is shown in Figure 2. The scheme can change with future work on the interactions of $\mathrm{pH}, \mathrm{ROS}$ and $\mathrm{NO}$, as indicated by broken lines. The interrelationships and interactions of cytosolic $\mathrm{Ca}^{2+}$, ROS, cytosolic $\mathrm{pH}$ and $\mathrm{NO}$ need therefore a detailed examination (Fig. 2). Further interactions of these secondary messengers with G-proteins, phospholipases and phosphatidylinositol kinases are all of great interest.

\section{Acknowledgements}

This work in our laboratory and preparation of this article are supported by grants from DBT (No. BT/PR9227/ PBD/16/748/2007), CSIR (No. 38(1195)/08/EMR-II) and a JC Bose National Fellowship of Dept of Science and Technology (No. SR/S2/JCB-06/2006) to A.S.R. all from New Delhi. V.K.G. was supported by a Senior Research Fellowship from CSIR, New Delhi.

\section{References}

1. Assmann SM, Shimazaki K. The multisensory guard cell: stomatal responses to blue light and abscisic acid. Plant Physiol 1999; 119:809-15.

2. Schroeder JI, Allen GJ, Hugouvieux V, Kwak JM, Waner D. Guard cell signal transduction. Ann Rev Plant Physiol Plant Mol Biol 2001; 52:627-58.

3. Hetherington AM, Woodward FI. The role of stomata in sensing and driving environmental change. Nature 2003; 424:901-8.

4. Irving HR, Gehring CA, Parish RW. Changes in cytosolic $\mathrm{pH}$ and calcium of guard cells precede stomatal movements. Proc Natl Acad Sci USA 1992; 89:1790-4.

5. Wang XQ, Ullah H, Jones AM, Assmann SM. G-protein regulation of ion channels and abscisic acid signaling in Arabidopsis guard cells. Science 2001; 292:2070-2.

6. Suhita D, Raghavendra AS, Kwak JM, Vavasseur A. Cytosolic alkalinization precedes reactive oxygen species production during methyl jasmonate-and abscisic acid-induced stomatal closure. Plant Physiol 2004; 134:1536-45.

7. Kolla VA, Vavasseur A, Raghavendra AS. Hydrogen peroxide production is an early event during bicarbonate induced stomatal closure in abaxial epidermis of Pisum sativum. Planta 2007; 225:1421-9.

8. Zhang X, Dong FC, Gao JF, Song CP. Hydrogen peroxide-induced changes in intracellular $\mathrm{pH}$ of guard cells precede stomatal closure. Cell Res 2001; 11:37-43.

9. Neill S, Barros R, Bright J, Desikan R, Hancock J, Harrison J, et al. Nitric oxide, stomatal closure and abiotic stress. J Exp Bot 2008; 59:165-76.

10. Gadjev I, Stone JM, Gechev TS. Programmed cell death in plants: New insights into redox regulation and the role of hydrogen peroxide. Int Rev Cell Mol Biol 2008; 270:87-144.

11. Mur LAJ, Carver TLW, Prats E. NO way to live; the various roles of nitric oxide in plantpathogen interactions. J Exp Bot 2006; 57:489-505.

12. Zhang A, Jiang M, Zhang J, Ding H, Xu S, Hu X, Tan M. Nitric oxide induced by hydrogen peroxide mediates abscisic acid-induced activation of the mitogen-activated protein kinase cascade involved in antioxidant defense in maize leaves. New Phytol 2007; 175:36-50.

13. Kolla VA, Raghavendra AS. Nitric oxide as an intermediate in bicarbonate-induced stomatal closure in Pisum sativum. Physiol Plant 2007; 130:91-8.

14. Srivastava N, Gonugunta VK, Puli MR, Raghavendra AS. Nitric oxide production occurs downstream of reactive oxygen species in guard cells during stomatal closure induced by chitosan in abaxial epidermis of Pisum sativum. Planta 2009; 229:757-65.

15. Lee S, Choi H, Suh S, Doo IS, Oh KY, Choi EJ, et al. Oligogalacturonic acid and chitosan reduce stomatal aperture by inducing the evolution of reactive oxygen species from guard cells of tomato and Commelina communis. Plant Physiol 1999; 121:147-52.

16. Pei ZM, Murata Y, Benning G, Thomine S, Klüsener B, Allen GJ, et al. Calcium channels activated by hydrogen peroxide mediate abscisic acid signalling in guard cells. Nature 2000; 406:731-4.

17. McAinsh MR, Pittman JK. Shaping the calcium signature. New Phytol 2008; 181:275-94

18. Lecourieux D, Lamotte O, Bourque S, Wendehenne D, Mazars C, Ranjeva R, Pugin A. Proteinaceous and oligosaccharidic elicitors induce different calcium signatures in the nucleus of tobacco cells. Cell Calcium 2005; 38:527-38.

19. Mazars C, Bourque S, Mithöfer A, Pugin A, Ranjeva R. Calcium homeostasis in plant cell nuclei. New Phytol 2008; 181:261-74.

20. Blatt MR. Cellular signaling and volume control in stomatal movements in plants. Annu Rev Cell Dev Biol 2000; 16:221-41.
21. Boonsirichai K, Sedbrook JC, Chen R, Gilroy S, Masson PH. ALTERED RESPONSE TO GRAVITY is a peripheral membrane protein that modulates gravity-induced cytoplasmic alkalinization and lateral auxin transport in plant statocytes. Plant Cell 2003; 15:2612-25.

22. Guern J, Mathieu Y, Thomine S, Jouanneau JP, Beloeil JC. Plant cells counteract cytoplasmic $\mathrm{pH}$ changes but likely use these $\mathrm{pH}$ changes as secondary messages in signal perception. Curr Top Plant Biochem Physiol 1992; 11:249-69.

23. Scott AC, Allen NS. Changes in cytosolic pH within Arabidopsis root columella cells play a key role in the early signaling pathway for root gravitropism. Plant Physiol 1999; 121:1291-8.

24. Feijo JA, Sainhas J, Hackett GR, Kunkel JG, Hepler PK. Growing pollen tubes possess a constitutive alkaline band in the clear zone and a growth-dependent acidic tip. J Cell Biol 1999; 144:483-96.

25. Felle HH. pH regulation in anoxic plants. Ann Bot 2005; 96:519-32.

26. Gonugunta VK, Srivastava N, Puli MR, Raghavendra AS. Nitric oxide production occurs after cytosolic alkalinization during stomatal closure induced by abscisic acid. Plant Cell Environ 2008; 31:1717-24.

27. Suhita D, Kolla VA, Vavasseur A, Raghavendra AS. Different signaling pathways involved during the suppression of stomatal opening by methyl jasmonate or abscisic acid. Plant Sci 2003; 164:481-8.

28. David JW, Colin RB, Anthony JM. The role of cytosolic potassium and $\mathrm{pH}$ in the growth of barley roots. Plant Physiol 1998; 118:957-64.

29. Hedrich R, Busch H, Raschke K. $\mathrm{Ca}^{2+}$ and nucleotide dependent regulation of voltage dependent anion channels in the plasma membrane of guard cells. EMBO J 1990; 9:3889-92.

30. Gehring CA, Irving HR, Parish RW. Effects of auxin and abscisic acid on cytosolic calcium and $\mathrm{pH}$ in plant cells. Proc Natl Acad Sci USA 1990; 87:9645-9.

31. Reiter CD, Teng RJ, Beckman JS. Superoxide reacts with nitric oxide to nitrate tyrosine at physiological pH via peroxynitrite. J Biol Chem 2000; 275:32460-6.

32. Neill S, Bright J, Desikan R, Hancock J, Harrison J, Wilson I. Nitric oxide evolution and perception. J Exp Bot 2008; 59:25-35.

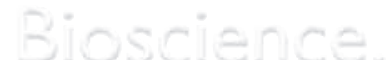

